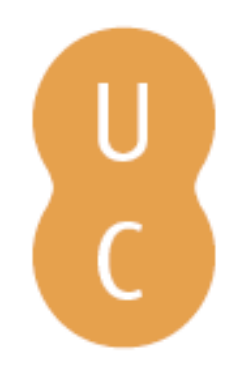

\title{
pompalina
}

\section{Festins de sangue: a tradição do banquete aziago em Plutarco}

Autor(es): $\quad$ Rodrigues, Nuno Simões

Publicado por: Imprensa da Universidade de Coimbra; Centro de Estudos Clássicos e

URL

persistente: URI:http://hdl.handle.net/10316.2/32000

DOI: $\quad$ DOI:http://dx.doi.org/10.14195/978-989-8281-17-3_21

Accessed : $\quad$ 26-Apr-2023 14:15:14

A navegação consulta e descarregamento dos títulos inseridos nas Bibliotecas Digitais UC Digitalis, UC Pombalina e UC Impactum, pressupõem a aceitação plena e sem reservas dos Termos e Condições de Uso destas Bibliotecas Digitais, disponíveis em https://digitalis.uc.pt/pt-pt/termos.

Conforme exposto nos referidos Termos e Condições de Uso, o descarregamento de títulos de acesso restrito requer uma licença válida de autorização devendo o utilizador aceder ao(s) documento(s) a partir de um endereço de IP da instituição detentora da supramencionada licença.

Ao utilizador é apenas permitido o descarregamento para uso pessoal, pelo que o emprego do(s) título(s) descarregado(s) para outro fim, designadamente comercial, carece de autorização do respetivo autor ou editor da obra.

Na medida em que todas as obras da UC Digitalis se encontram protegidas pelo Código do Direito de Autor e Direitos Conexos e demais legislação aplicável, toda a cópia, parcial ou total, deste documento, nos casos em que é legalmente admitida, deverá conter ou fazer-se acompanhar por este aviso.

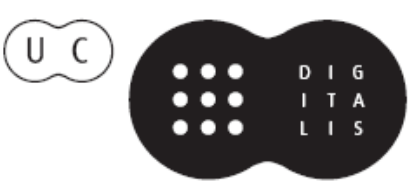




\section{Symposion and Philanthropia in Plutarch}

\section{José Ribeiro Ferreira, Delfim Leão Manuel Troster e Paula Barata Dias (eds.)}

IMPRENSA DA UNIVERSIDADE DE COIMBRA 


\title{
Festins de SAngue: A TRAdição do banquete aziago em Plutarco
}

\author{
Nuno Simões Rodrigues \\ Universidade de Lisboa
}

\begin{abstract}
This paper's title evokes García Lorca's play Bodas de Sangre. In fact, the strong contrast we can find between the feast and the blood is used several times by Plutarch in his Vitae. But the Author only follows an ancient literary tradition that can be found in mythological texts as well as in epic and tragic poetry or even in historiography. So, Plutarch makes an important contribution to what we call "pathetic History". Our aim is to demonstrate how well Plutarch fits in this tradition, discussing his qualities and interests as Historian.
\end{abstract}

$\mathrm{Na}$ biografia que escreveu de Teseu, Plutarco assinala que, quando Pirítoo desposou Deidamia, os centauros foram convidados para a boda. Nunca tendo provado vinho antes, porém, quando o fizeram, a natureza selvagem dos centauros revelou-se e estes tornaram-se agressivos, desejando violentar as mulheres presentes no festim ${ }^{1}$. O que deveria ter sido uma festa, qual expressão da ordem e da harmonia, terminou em agressões e sangue, acabando por conferir ao banquete de casamento um carácter funesto e caótico.

$\mathrm{Na}$ vida do rei Artaxerxes II, Plutarco conta que Parisatis, a rainha-mãe, envolvida nas teias e intrigas políticas da corte persa, decide eliminar a nora, a rainha Estatira, dado o ciúme e a inveja que nutria por ela ${ }^{2}$. Para o efeito, organiza um banquete de reconciliação. Escreve Plutarco, baseado em Ctésias e em Dínon, que, apesar de reconciliadas, as duas rainhas temiam-se mutuamente, pelo que apenas comiam o que a outra também comia e que era servido sempre pelas mesmas mãos. Mas ainda assim Parisatis conseguiu introduzir veneno na refeição, oferecendo à nora um pedaço de carne contaminada. Estatira acabou envenenada, no meio de fortes convulsões e grandes sofrimentos ${ }^{3}$.

Segundo Plutarco, também a biografia de Alexandre-o-Grande foi influenciada pelo distúrbio ocorrido durante um banquete em que pai e filho se defrontaram, ao ponto de Alexandre se ter retirado com a mãe da casa paterna e refugiado na Ilíria, enquanto Olímpia era levada para o Epiro. Na sequência destes acontecimentos, será relatada a morte de Filipe ${ }^{4}$. Na mesma vida, um outro banquete, em que Alexandre promove um concurso de bebida de vinho, acaba por terminar na morte de quarenta e dois dos convivas ${ }^{5}$.

${ }^{1}$ Plu., Thes. 30, 3. Este é o tema que decorava o pedimento ocidental do templo de Zeus, em Olímpia. Nesse conjunto escultórico, a figura de Apolo, ao centro, representa a reposição da ordem, a que se deseja regressar após a experiência do caos. Sobre esta questão dissertou já G. PAUL, 1991, p. 160; sobre as funcionalidades do vinho neste contexto, ver o nosso estudo, 2001.

${ }^{2}$ Plu., Art. 19. Sobre esta Vida, ver o estudo de C. SoAres, 2008.

${ }^{3}$ Plu., Art. 19, 7. Uma análise deste passo pode também ser lida no estudo de D. Romero González, neste mesmo volume, pp. 255-60.

${ }^{4}$ Plu., Alex. 9.

${ }^{5}$ Plu., Alex. 70. 
$\mathrm{Na}$ vida de Sertório, o autor das Vidas afirma que o general romano mantinha sempre um nível de austeridade e decoro nos banquetes em que participava. Num desses festins, porém, os inimigos de Sertório decidiram aproveitar-se da ocasião para lhe montar uma armadilha. Fingiram estar embriagados e comportarem-se de forma desordeira, de modo a enfurecerem o anfitrião. Sertório tentou fingir que nada o afectava. Ainda assim, os conspiradores levaram o plano avante e assassinaram Sertório enquanto este, impotente, se mantinha reclinado no seu leito ${ }^{6}$.

Também na vida de Crasso, Plutarco informa que foi com um banquete que Orodes, o rei dos Partos, comemorou, juntamente com Artavasdes, o rei arménio, a derrota romana em Carras, no ano 53 a.C. Segundo o relato plutarquiano, os reis orientais assistiam então a uma representação de $A s$ Bacantes de Eurípides, viam a cena em que a rainha Agave surge com a cabeça de Penteu. Terá sido precisamente nessa ocasião que um mensageiro entrou no salão com a cabeça de Crasso, que foi aproveitada pelo actor que interpretava Agave, de modo a conferir mais realismo ao momento ${ }^{7}$. Mas os acontecimentos deste festim pressagiam também o castigo que acabou por cair sobre Orodes e a crueldade demonstrada ao longo da sua vida ${ }^{8}$.

Os exemplos citados, a que poderiamos juntar alguns outros, comungam do facto de serem relatos historiográficos, supostamente históricos, enquadrados por um ambiente simposíaco, que confere um estilo patético à narração dos acontecimentos ${ }^{9}$. A utilização do banquete como tema narrativo ou eixo director da descrição dos eventos foi já reconhecida como uma das características do estilo plutarquiano, com particular presença nas Vidas.$^{10}$ A título de exemplo da sua importância, podemos referir o inesquecível passo da vida de António, em que o autor descreve o ambiente no palácio de Cleópatra, em Alexandria, o qual contribui para que o casal protagonista do texto fosse conhecido entre os seus contemporâneos como "os da vida inimitável"11.

O tema em si, porém, está longe de ser uma criação original do tratadista de Queroneia. O motivo do festim maldito, em particular - aquele em que nos centramos -, aparece nas literaturas antigas desde muito cedo. Apresentamos alguns exemplos.

Já na Odisseia, no canto em que Circe recebe os companheiros de Ulisses, lemos que a feiticeira os assentou e lhes serviu queijo, cevada, mel e vinho, aos

${ }^{6}$ Plu., Sert. 26. Uma análise deste passo pode também ser lida no estudo de I. MuÑoz Gallarte, neste mesmo volume, pp. 245-257.

${ }^{7}$ Plu., Crass. 33.

${ }^{8}$ Plu., Crass. 33, 7-9.

${ }^{9}$ Ver e.g. Plu., Pel.9, 4-11; Dem.36, 4-12; Pyrrh. 5, 7-14; Cleom.7-8. Alguns destes banquetes incluem o vinho como motivo desencadeador do conflito.

${ }^{10}$ A importância do banquete na obra de Plutarco foi reconhecida pelo facto de o autor lhe ter dedicado uma obra, Symposiaka. As funções do banquete nas Vidas foram já destacadas por G. Paul, 1991 e por F. B. Titchener, 1999. Paul refere outros tratamentos da vida de Alexandre, por exemplo, onde o banquete aziago está igualmente presente.

${ }^{11}$ Plu., Ant. 28, 2. 
quais juntou terríveis drogas, cujo objectivo era transformá-los em porcos ${ }^{12}$. O banquete de Circe tem, portanto, um objectivo nefasto, anunciando a desgraça que está para acontecer aos companheiros de Ulisses. No mesmo poema, o desenlace da história do regresso de Ulisses a Ítaca dá-se com a organização de um banquete, onde, desde o início, a tragédia espreita. O Poeta refere-se-lhe do seguinte modo:

Mas nenhuma refeição podia ser mais desgraciosa do que aquela que uma deusa e um homem forte estavam prestes a oferecer-lhes ${ }^{13}$.

É no contexto deste banquete que Penélope consegue que se realize a prova do arco, na sequência da qual ocorre a mortandade dos pretendentes às mãos de Ulisses, trazendo um desfecho inesperado e sangrento à festa ${ }^{14}$. É ainda na Odisseia que se conta uma variante do mito de Agamémnon. Segundo esta versão, que difere da contada por Ésquilo, Egisto teria recebido o rei de Argos/ Micenas, regressado da guerra de Tróia, com um festim, que aproveitou para o matar o atrida "como a um boi" ${ }^{15}$. A mesma tradição será seguida por Séneca que, na tragédia Agamémnon, traz o registo da morte do rei à cena recorrendo à típica descrição coral, que evoca o motivo do banquete sangrento ${ }^{16}$.

Radicado no mito de Agamémnon, conta-se o de Atreu, de quem aquele rei é dito descendente. A maldição que na mitologia grega se cola à família dos Atridas justifica-se precisamente com um acontecimento, in illo tempore, cujo acme ocorre durante um banquete maldito. A história de Atreu, filho de Pélops e Hipodamia, é preenchida pelo ódio deste ao irmão Tiestes, bem como pelas vinganças que os dois irmãos planearam alternadamente um contra o outro. Depois de Tiestes se ter tornado amante da cunhada, Aérope, Atreu concebeu o plano de dar a comer ao irmão os próprios filhos dele, num banquete propositadamente preparado para isso ${ }^{17}$. O acto horrendo de Atreu fez cair a vingança dos deuses sobre si e sobre todos os seus descendentes. $\mathrm{O}$ mesmo enredo pode ser lido nos mitos de Tântalo, Licáon e Tereu.

O primeiro é tido como um dos ascendentes dos Atridas, o que transforma a característica do festim maldito num topos familiar, que eventualmente traduz a repetição de um mesmo motivo numa família mitológica ${ }^{18}$. Segundo a tradição mitológica, Tântalo teria imolado o seu filho Pélops para servilo em forma de guisado, num banquete, aos deuses. A crer em alguns dos autores antigos, Tântalo tê-lo-ia feito por piedade, numa época em que a fome grassava na Hélade e não havia outra vítima para oferecer às divindades. Outros consideravam que Tântalo quis pôr à prova a clarividência divina. Seja

\footnotetext{
12 Od. 10, 233-240.

${ }^{13}$ Od. 20, 392-393, em trad. F. Lourenço.

${ }_{14}$ Od. 21-22.

${ }^{15}$ Od. 4, 519-537.

${ }^{16}$ Sen., $A g .875-909$.

${ }^{17}$ Sen., Thy.; A. A. 1590-1601.

${ }^{18}$ I.e., poderemos estar perante uma mesma estrutura de um mito, que ganhou formas de acordo com as variações locais-geográficas e temporais-cronológicas.
} 
como for, todos os deuses reconheceram a carne que lhes estava a ser servida, à excepção de Deméter, cuja fome não impediu que devorasse um ombro da vítima ${ }^{19}$. Mas os deuses acabaram por reconstruir o corpo de Pélops, a quem foi assim concedida a ressurreição. No lugar do ombro devorado, foi colocada uma prótese de marfim.

Quanto a Licáon, contava-se entre os Gregos que este era um rei piedoso e que por isso mesmo os deuses o visitavam amiúde. Os filhos do rei, contudo, quiseram saber se as visitas da casa eram efectivamente deuses, pelo que mataram uma criança e misturaram as suas carnes com as da vítima que havia sido preparada para o banquete. Os deuses, horrorizados com o que viram, fulminaram os culpados. Uma variante do mito, porém, reza que, tanto Licáon como os filhos, eram ímpios e que, um dia, Zeus decidiu testar o grau da impiedade do homem. Visitou-o, na forma de um camponês, e Licáon, suspeitando de que poderia tratar-se de um deus, decidiu pôr o hóspede à prova, servindo-lhe a carne de uma criança num banquete. A ira de Zeus levou a que Licáon fosse fulminado ${ }^{20}$.

O mito de Tereu contém igualmente o topos da criança sacrificada e servida num festim. Apesar de casado com Procne e desta ter um filho, Tereu inflamouse de paixão pela cunhada Filomela. Tereu violou Filomela e, para evitar que esta o denunciasse, cortou-lhe ainda a língua. Mas Filomela encontrou forma de contar o que se havia passado, bordando a sua história num pano. Conhecedora da verdade, Procne decidiu então vingar-se do marido, matando o próprio filho, Ítis, cozinhando as carnes da criança e servindo-as ao marido, que as comeu sem suspeitar de nada ${ }^{21}$. Aquiles Tácio refere-se no seu romance a este mito, numa écfrase, que termina do seguinte modo:

Era assim que o artista tinha concebido a cena bordada no tecido da tela. Quanto ao resto do quadro, as mulheres mostravam a Tereu, numa cesta, os restos do banquete: a cabeça e as mãos de seu filho; riam, mas ao mesmo tempo estavam apavoradas. Tereu estava representado a saltar do leito e, sacando da espada contra as mulheres, dava um empurrão à mesa com a perna; a mesa nem estava de pé, nem estava por terra, dando antes a impressão de que era o quadro que estava na iminência de cair ${ }^{22}$.

Outro mito em que pontificava o tema do banquete aziago era o das Leucípides. A história destas filhas de Leucipo e sobrinhas de Tíndaro-primas portanto de Helena e de Clitemnestra, as esposas dos Atridas - resume-se à luta que, por sua causa, opôs os Dioscuros, seus primos, a dois outros primos, filhos de Afareu. No festim que Castor e Pólux ofereceram em Esparta a Eneias e Páris, quando estes visitaram Menelau com o objectivo de raptar Helena, os

${ }^{19}$ Ov., Met. 6, 401-411.

${ }^{20}$ Apollod., Bib. 3, 8, 1; Ov., Met. 1, 196; Paus., 8, 2, 1-2. Alguns autores consideram que estas lendas estão relacionadas com antigos sacrifícios humanos, associados ao culto de Zeus Licáon.

${ }^{21}$ Paus. 1, 41, 8; 10, 4, 8; Apollod., Bib. 3, 14, 8; Ov., Met. 6, 426-674; Ach. Tat. 5, 3.

${ }_{22}$ Ach. Tat. 5, 3, 7-8, em trad. A. N. Pena. 
filhos de Afareu, motivados pelo vinho que haviam ingerido, censuraram os Dioscuros por se terem casado sem terem oferecido um dote ao tio. Insultados, Castor e Pólux reagiram e a discussão acabou num violento confronto, que levou à morte de um dos gémeos, bem como de dois dos seus primos ${ }^{23}$.

Como se confirma, são vários os episódios mitológicos gregos que aludem ao tema do festim maldito ou aziago. A sua pertinência é de tal modo assinalável que até mesmo as bodas de Peleu e Tétis se celebram num banquete cujo desfecho culmina naquela que veio a ser a mais sangrenta e simbólica das guerras do imaginário grego ${ }^{24}$.

Mas o tema em causa não surge exclusivamente na mitologia. Ele está igualmente presente nas tradições históricas e historiográficas gregas, ainda que com funcionalidades razoavelmente diferentes, como atestam os casos de Simónides e de Heródoto ${ }^{25}$. As Histórias de Hérodoto são, aliás, particularmente ricas nesta temática. $\mathrm{O}$ autor inclui uma série de banquetes, supostamente factuais - o que não é linearmente exacto -, em que a desgraça é a protagonista. Independentemente da factualidade, interessa-nos destacar a pertinência da sua presença na narrativa ${ }^{26}$. A propósito da egípcia Nitócris, por exemplo, o "Pai da História" refere que, depois de lhe terem matado o irmão e entregado o poder, a rainha convidou os egípcios que considerava terem sido os assassinos do parente a participarem num sumptuoso festim. Enquanto eles se banqueteavam, a rainha fez cair sobre eles as águas do rio, através de uma conduta secreta ${ }^{27}$. Em Heródoto, encontramos também o relato de um banquete que evoca os mitos de crianças cozinhadas, acima referidos. Concedamos voz ao próprio historiador, a propósito de Astíages, rei dos Medos, que deseja vingar-se de Hárpago, por este não ter matado Ciro quando ele era ainda criança, tal como lhe havia sido ordenado:

Ao ouvir estas palavras, Hárpago prostrou-se e, de regresso a casa, considerou uma grande sorte que o seu erro tivesse acabado em bem e que, sob tão bons auspícios, o tivessem convidado para jantar. Mal chegou, mandou a toda a pressa o único filho que tinha, que andava pelos treze anos, com a recomendação de se dirigir ao palácio de Astíages e fazer aquilo que o rei lhe ordenasse. Ele próprio, exultante de alegria, contou à mulher o sucedido. Astíages, quando o filho de Hárpago chegou, mandou-o degolar e esquartejar em pedaços; uma parte das carnes assou-a, outra cozeu-a, e pôs tudo pronto a servir. Quando chegou a hora do jantar e Hárpago e os outros convivas compareceram, a todos os presentes e ao próprio Astíages foram servidas mesas repletas de carne de carneiro, a Hárpago, o corpo inteiro do filho, menos a cabeça, mãos e pés; estas partes ficaram de lado, dentro de um cesto, e cobertas. Logo que Hárpago pareceu satisfeito, Astíages perguntou-lhe se

${ }^{23}$ Theoc. 22; Apollod., Bib. 3, 11, 2.

${ }^{24}$ Apollod., Bib. 3, 13, 4-5.

${ }^{25}$ Isso porque o tema da criança cozinhada e oferecida em banquete parece ter tido um objectivo específico ou derivado de situações concretas, como a possibilidade de estar relacionado com eventuais sacrifícios humanos antigos. Sobre esta problemática, ver L. N. FERreira, 1996; M. Halm-Tisserant, $2007^{2}$.

${ }^{26}$ Do mesmo modo que nos interessa assinalar a inclusão de episódios como o de Giges e Candaules ou o de Aríon e o golfinho.

${ }^{27}$ Hdt. 2, 100. 
tinha gostado do festim. Perante a resposta de que tinha gostado muito, aqueles que estavam incumbidos dessa missão trouxeram a cabeça, as mãos e os pés do rapaz, ainda cobertos; dirigiram-se a Hárpago e convidaram-no a destapar o cesto e a servir-se do que quisesse. Este obedeceu, e, ao destapá-lo, viu os restos do filho. Mas, perante o espectáculo, não se perturbou nem perdeu o auto-domínio. Astíages perguntou-lhe se sabia de que animal eram as carnes que tinha comido. Ele respondeu que sim e que aceitava tudo o que o rei fizesse. Depois desta resposta, pegou no resto das carnes e voltou para casa ${ }^{28}$.

Como facilmente se conclui, o banquete canibal de Astíages reflecte os dos mitos de Tântalo e Atreu, confirmando a contaminação da historiografia grega pelas temáticas mitológicas ${ }^{29}$. Mas a sua inclusão no relato funciona sobretudo pelo dramatismo e pelo tom patético que lhe dá forma. No mesmo livro, Heródoto relata também um plano de Creso e Ciro para aniquilar os Masságetas, seus inimigos. Estes são neutralizados através de um lauto banquete que lhes é oferecido. $\mathrm{O}$ abuso da comida e da bebida deixa-os totalmente incapazes de reagir contra os Persas que os atacam ${ }^{30}$. É ainda em Heródoto que encontramos relato de um outro festim, igualmente marcado pelo desfecho funesto, apesar de essa não ter sido uma intenção premeditada, como acontece com outros casos. Trata-se do momento em que Amintas, rei da Macedónia, convida os Persas a banquetearem-se na sua casa. Estes, saciados de comida e de bebida, pedem ao anfitrião que, à maneira persa, as mulheres do palácio se juntem aos convivas, ainda que esse não seja um costume grego. Amintas acaba por anuir, mas os convidados, embriagados, não se refreiam e começam a exceder-se no seu comportamento, em relação às mulheres presentes. É então que Alexandre, o filho de Amintas, engendra um plano para inverter a situação a seu favor: faz sair as mulheres do festim e substitui-as por outros tantos mancebos, vestidos de mulheres e armados de punhais. Estes acabam por matar os Persas, marcando o festim com sangue ${ }^{31}$. A semelhança de outros episódios herodotianos, também neste reconhecemos a influência da mitologia, mais concretamente do mito das bodas de Deidamia e Pirítoo, acima referido. No livro IX do mesmo historiador, regista-se outro episódio ainda particularmente revelador das contaminações temáticas na historiografia antiga. Trata-se da história da túnica de Xerxes. Heródoto conta que a rainha Améstris, mulher de Xerxes, teria oferecido ao marido uma túnica feita pelas suas próprias mãos. $\mathrm{O}$ rei, porém, viu-se obrigado a oferecê-la à nora, Artainte, por quem estava apaixonado, e que era também filha da cunhada do rei, por quem ele se havia enamorado antes. Ao tomar conhecimento do que se passara, Améstris elabora o seu plano de vingança e para o efeito aproveita a festa de aniversário do rei, pois sabia que nessa o

${ }^{28}$ Hdt. 1, 119, em trad. M. F. Silva in Heródoto, Histórias I, trad., introd. e notas de M. F. Silva e J. Ribeiro Ferreira, Lisboa, 1994.

${ }^{29}$ Sobre este problema, ver o nosso estudo, 2007.

${ }^{30}$ Hdt. 1, 207. Sobre este episódio, ver C. Coulet, 1994, p. 63; S. Flory, 1987, pp. 42-3.

${ }^{31}$ Hdt. 5, 19-20. Este banquete tem algumas semelhanças com o narrado em Plu., Pel. 9 , 4-11, designadamente o elemento eonista. 
monarca estava obrigado a atender a todos os pedidos que lhe fossem feitos nessa ocasião ${ }^{32}$. Améstris decide pedir ao marido que lhe seja entregue a cunhada, mãe de Artainte, que considerava ser a culpada daquela situação. Améstris deixa então emergir a vingança de uma forma atroz sobre aquela que considera sua rival, concretizada com a mutilação sádica e impiedosa do nariz, das orelhas, dos lábios, da língua e dos seios da cunhada ${ }^{33}$. A ocasião que proporciona tamanha barbaridade é precisamente a do banquete real ou "Ceia Real”, como Heródoto the chama ${ }^{34}$. Em contexto herodotiano, poderíamos citar ainda o banquete aziago de Atagino, pouco antes da batalha de Plateias, em que um persa prevê a desgraça dos seus conterrâneos no confronto que se aproxima, permitindo o contraste entre a alegria da refeição tomada em comum por Persas e Gregos e a morte que se anuncia e aproxima ${ }^{35}$.

Em relação a Simónides de Ceos, há que assinalar a antiga tradição que referia que o poeta, depois de ter estado presente num banquete na casa da família de Escopas, teve de regressar ao local do festim para identificar os corpos dos convivas que haviam sido soterrados, na sequência do desabamento do tecto da sala. Um dos testemunhos do episódio é Cícero, que conta que o banquete se realizou na casa de Crânon e que o tecto desabou pouco tempo depois de o poeta de Ceos ter abandonado o local $^{36}$. O momento de festa foi, portanto, totalmente ofuscado pela tragédia que se lhe seguiu. $\mathrm{Na}$ verdade, as opiniões acerca da facticidade do episódio divergem, não faltando os autores que consideram que se trata de uma mera tradição sem qualquer fundamento verídico ${ }^{37}$.

Uma história muito semelhante pode ser lida em Tácito e Suetónio, contemporâneos de Plutarco, a propósito do principado de Tibério. No autor dos Annales, lemos que certo dia, enquanto Tibério jantava numa uilla conhecida como "A caverna", pois localizava-se numa gruta natural, a abóbada soltou-se e parte do tecto caiu, esmagando alguns dos servos. Tácito acrescenta mesmo que terá sido Sejano, o prefeito do pretório, quem salvou o imperador, sobrepondo-se sobre o corpo do príncipe ${ }^{38}$. O mesmo relata Suetónio, sem no entanto se referir explicitamente a Sejano ${ }^{39}$. O que nos interessa destacar deste episódio, porém, tenha ele efectivamente ocorrido ou não, é que uma vez mais o festim foi marcado pela tragédia, sendo por isso significativa a sua inclusão na narrativa pelos historiadores antigos.

${ }^{32}$ A. M. Bowie, 2003, destaca o facto de este ser um tema oriental, uma vez que exalta o rei e o seu poder enquanto indivíduo; ver ainda O. STRID, 2006.

${ }^{33}$ Hdt. 9, 108-13. Ver C. Soares, 2003, pp. 353-9; E. Wolf f, 1964.

${ }^{34}$ Hdt. 9, 110.

${ }^{35}$ Hdt. 9, 16. Tema já salientado por C. Coulet, 1994, p. 64. O passo em que Heródoto conta uma das versões da forma como Cambises provoca a morte da sua esposa-irmã sugere que tudo se terá passado durante um banquete, Hdt. 3, 32. Ver ainda Hdt. 3, 34-35; L. EDmunds, 1987.

${ }^{36}$ Cic., Orat. 2, 86, 351-353; Quint., Inst. 11, 2, 11-16.

${ }^{37}$ Uma discussão do passo pode ser lida em L. N. Ferreira, 2005, pp. 138-40.

${ }^{38}$ Tac., Ann. 4, 59. Trata-se da célebre gruta de Spelunca, onde foram encontradas esculturas alusivas à Odisseia.

${ }^{39}$ Suet., Tib. 39. 
É ainda da historiografia romana que nos chega o relato de pelo menos mais quatro exemplos de festins fúnebres. $\mathrm{O}$ primeiro decorreu durante o principado de Cláudio e diz respeito ao processo que desencadeou a execução da sua mulher, a imperatriz Valéria Messalina. É na sequência de um banquete orgíaco de características trágico-dionisíacas que Messalina é acusada de ter praticado bigamia e conspirado contra o imperador. Estas acusações acabarão por levar a imperatriz à morte, bem como muitos dos que com ela se envolveram no festim báquico ${ }^{40}$. O segundo exemplo data do final do mesmo principado. Ou melhor, marca o final desse mesmo principado, dado que Suetónio levanta a suspeita de Cláudio ter sido envenenado durante um banquete que se realizou no Capitólio $^{41}$. O terceiro caso data do principado de Nero e referese ao homicídio de Britânico, precisamente o filho de Messalina e Cláudio. Tácito conta, pormenorizadamente, que foi durante um banquete que o jovem príncipe foi envenenado por Nero, através de uma estratégia digna da que Plutarco regista para o episódio de Parisatis e Estatira ${ }^{42}$. É ainda através de Tácito e Suetónio que ficamos a saber que o mesmo Nero maquinou a morte da própria mãe, Agripina Menor, a quem atraiu a um banquete para depois a fazer entrar num navio preparado para naufragar ${ }^{43}$. Quatro situações fúnebres, germinadas em outros tantos festins.

Estes são alguns exemplos que, quanto a nós, comprovam quão difundido era o tema do festim maldito na literatura greco-latina, no tempo de Plutarco. Mas o topos teve um êxito com ecos bem além desse universo. Efectivamente, ele estava já presente nas literaturas orientais pré-clássicas e suas herdeiras. Podemos encontrá-lo, por exemplo, nas culturas do mundo bíblico, em diversos episódios e textos. $\mathrm{Na}$ história de José, a morte do padeiro-mor da corte egípcia é decretada enquanto decorre o banquete de aniversário do faráo ${ }^{44}$. No livro dos Juizes, o relato da vida de Sansão, uma narrativa de forma deuteronomística com contornos épico-trágicos, romanescos e folclóricos datada de entre os séculos VIII e VI a.C. ${ }^{45}$, recorre ao tema por duas vezes. A primeira enquadra o relato do casamento do herói com uma filisteia. Sansão oferece um banquete, em que propõe um enigma a um grupo de jovens. Estes, incapazes de decifrar o que lhes foi apresentado, decidem chantagear a mulher de Sansão, para que ela obtenha do marido a resposta desejada. A filisteia cede e trai o marido. Sansão acaba por revelar-lhe a resposta e a mulher transmite-a aos interessados. Irado por ter sido enganado, Sansão mata os jovens ${ }^{46}$. A segunda vez contextualiza o episódio da morte do herói. Conta-se que os príncipes dos Filisteus se

${ }^{40}$ Tac., Ann. 11, 26-32. Analisámos já este episódio, bem como os ecos mitológico-literários que nele podemos descortinar, em 2003.

${ }^{41}$ Suet., Cl. 44.

${ }^{42}$ Tac., Ann. 13, 16.

${ }^{43}$ Suet., Nero 34; Tac., Ann. 14, 3-4.

${ }^{44} G n$ 40, 20-23. É esse mesmo acontecimento que faz com que o copeiro-mor não volte a recordar-se de José, que ficou na prisão; ver H. Gunkel, 1964 (1 $1^{\text {a }}$ ed., 1901).

${ }^{45}$ Ver R. G. Boling, 1975, pp. 30-1; J. Nunes Carreira, 1993, p. 211.

${ }^{46} \mathrm{Jz}$ 14, 10-20. No célebre filme de Cecil B. De Mille, de 1949, o argumentista nomeou a mulher de Sansão como Semadar. 
reuniram para oferecer um sacrifício a Dagon e celebrar um banquete. É nesse contexto que Sansão, já cego graças à traição de Dalila - o motivo de Dalila como que repete o da mulher filisteia na história do mesmo herói -, se coloca sob as colunas do templo e fá-lo ruir, esmagando todos os que se encontravam no seu interior ${ }^{47}$.

Outro episódio bíblico em que o banquete proporciona a desgraça pode ser lido no livro de Judite, texto judaico que nos chegou na sua versão grega. Apesar de enquadrado no tempo de Nabucodonosor (secs. VII-VI a.C.), a composição deste "romance" deverá datar do século II a.C., mais especificamente do tempo de Antíoco IV Epifânio (168-163 a.C.) ${ }^{48}$. O texto gira em torno de uma bela judia, epónima dos próprios Judeus, que decide tomar parte activa no conflito que opõe Assiro-babilónios a Hebreus/Judeus, matando um dos generais inimigos. Para isso, Judite aceita participar num banquete organizado pelo inimigo Holofernes, que, vencido pelo vinho, acaba decapitado às mãos da bela mulher ${ }^{49}$.

No livro de Daniel, igualmente datado do período helenístico, encontramos também um episódio que assume a forma do festim maldito. Trata-se do banquete de Baltasar, no qual o rei babilónio, depois de ter abusado do vinho, decide fazer introduzir no festim os vasos de ouro e prata que Nabucodonosor havia tirado do templo de Jerusalém. Depois de todos os convivas terem bebido pelos objectos referidos, decidem louvar os deuses de Babilónia. É nesse momento que surge do nada uma mão humana que escreve nas paredes do palácio uma frase enigmática. É o profeta Daniel quem acaba por decifrar o seu significado, por indicação da rainha. O enigma anunciava o fim de Baltasar. Diz o texto que "na mesma noite, foi morto Baltasar, rei dos caldeus" ${ }^{50}$. Uma vez mais, o banquete serve de pretexto para o anúncio da desgraça.

Há ainda dois outros banquetes bíblicos aziagos que não podemos deixar de referir neste estudo, dada a pertinência do seu enquadramento e dos motivos a que dão forma. O primeiro deles é o celebre "Banquete de Herodes", que assinala o aniversário do tetrarca Herodes Ântipas e que motiva a execução de João Baptista. Reconhecemos nesta história, aliás, vários motivos comuns à que assinalámos acima, a propósito de Xerxes, Améstris e Artainte. São diversos os elementos comuns entre o relato de Heródoto e o que encontramos nos Evangelhos de Mateus e de Marcos. Estes referem que o tetrarca da Galileia se comprometeu publicamente, no dia do seu aniversário, em oferecer à filha de Herodíade o que a jovem pedisse como recompensa por ter dançado nessa ocasião. A princesa, que Flávio Josefo identifica como sendo Salomé, é instigada pela mãe a pedir a cabeça do Baptista num prato ${ }^{51}$. A forma como a

${ }^{47} \mathrm{Jz}$ 16, 23-31.

${ }^{48}$ Ver J. A. Ramos, 2005, pp. 45-6.

${ }^{49} \mathrm{Jdt}$ 12-13.

${ }^{50}$ Dn 5, em trad. J. A. Ramos in Nova Bíblia dos Capuchinhos, Lisboa/Fátima, 1998.

${ }^{51} M t$ 14,3-12, Mc 6,17-29; J., AJ 18, 110-111, 136-137, 148, 240. O ódio de Herodíade por João explica-se pelo facto de o profeta denunciar o casamento tido como incestuoso entre esta princesa e o seu cunhado, Herodes Ântipas. Curiosamente, o nome da jovem permanece oculto nos textos bíblicos. 
narrativa é apresentada sugeriu já vários estudos, em particular de autores com formação jungiana, que a relacionam com os antigos mitos telúricos, centrados nas figuras da mãe e da filha ${ }^{52}$. Mas a sua estrutura recorda igualmente o episódio herodotiano do livro IX, em que Ântipas se assume como alter-ego de Xerxes, Herodíade de Améstris e Salomé de Artainte. A comunhão dos dois casos faz-se com o banquete maldito, que acaba por suscitar a desgraça de alguém. Se existe ou não relação entre ambos os textos, não o sabemos nem é este o lugar para proceder a uma discussão em torno dessa problemática. Mas o que nos parece indubitável é a semelhança tópica do leit motiv que dá sentido à narrativa.

Foi já notado que o banquete de Herodes prefigura uma inversão da Ceia eucarística ${ }^{53}$. Assim poderá ser entendido, se tivermos em conta a inclusão de ambos os episódios nos mesmos Evangelhos, bem como a funcionalidade de cada uma das narrativas na economia dos textos em que se inserem. Mas consideramos que a Última Ceia, tal como vem narrada nos textos sinópticos e apesar da sua funcionalidade etiológica no âmbito da instituição do cristianismo como religião e ritual, configura igualmente um outro banquete aziago. Não é em torno desse banquete que se anuncia, processa e concretiza a traição de Jesus de Nazaré por Judas Iscariotes, que acaba com a prisão do Nazareno e sua posterior condenação e execução?

Os textos e tradições assinalados são anteriores ou contemporâneos das $V i d a s$ de Plutarco, o que nos leva a concluir que, no que diz respeito ao estilo, ao método e à forma, o tratadista de Queroneia estava bem apoiado para a composição das biografias que escreveu, tanto por exempla mitológicos, como por tradições e topoi literários em geral, mas particularmente associados à historiografia - não podemos esquecer que os textos bíblicos são supostamente História, quer para a cultura judaica quer para a cristã. Trouxemos à colação apenas alguns exemplos que o provam. Longe de se associar exclusivamente ao banquete de tipo oriental ${ }^{54}$, o carácter aziago, nefasto ou maldito de alguns dos festins referidos por Plutarco parece antes seguir uma tradição, cuja escolha não é isenta ou inocente ${ }^{55}$. Efectivamente, a opção de conferir um contexto a um momento que seria supostamente festivo e que se transforma numa catástrofe para os que nele intervêm tem um efeito retórico de significativa eficácia poético-historiográfica, uma vez que a funcionalidade festiva e positiva é substituída pelo inesperado final aziago e negativo, produzindo o efeito contrário do que se espera ${ }^{56}$. A sua utilização poderá mesmo traduzir uma intencionalidade "suspensiva" na narrativa, contribuindo para o que ficou definido como historiografia patética e que

${ }^{52}$ C. G. Jung \& C. Kerényi, 2002, em especial as pp. 119-83. Ver ainda B. L. KnApp, 1977.

${ }^{53}$ Mt 26,17-29; Mc 14,12-25; Lc 22,7-20; M. Dottin-Orsini, 1998, p. 14.

${ }^{54}$ A. M. Bowie, 2003, p. 107.

55 Apesar de alguns dos exemplos citados sobressaírem pelo tema da criança sacrificada, e mesmo tendo em conta que esse é o tópico principal dessas narrativas, quisemos salientar que outro elemento que lhes é comum na condução da narrativa é o do banquete aziago.

${ }^{56}$ Sobre o uso do banquete em geral na historiografia, ver G. PAul, 1991, p. 158. 
dominou o estilo dos historiadores durante grande parte da Antiguidade Clássica, particularmente a que floresceu durante o período da Segunda Sofística. Além disso, o método repete-se com alguma frequência. Veja-se como um passo do segundo livro dos Reis, por exemplo, é significativamente enriquecido, na paráfrase correspondente de Flávio Josefo, ao se acrescentar um banquete aziago à narrativa em causa ${ }^{57}$.

Note-se também como a maioria destas narrativas tem o vinho e a sua introdução no ambiente do festim como agente catalisador da acção. É a partir do momento em que os convivas o ingerem que estes ficam inoperacionais ou, em contrapartida e no extremo da acção, se revelam elementos perturbadores do ambiente em que estão inseridos. Este é portanto um topos complementar do motivo do banquete aziago ${ }^{58}$. $\mathrm{O}$ vinho revela-se um dos instrumentos que proporciona que o festim, cujo conceito se associa à ideia de comunhão eucarística, logo de felicidade, se torne através de uma contrafacção no seu próprio contrário e passe a simbolizar o mundo às avessas ou caos ${ }^{59}$. A alegria inicial e expectável é contradita pela fatalidade que se sucede. Ao revelar-se negativo, o que deveria ser supostamente positivo enfatiza a desgraça. Ao evocarmos a obra de Lorca no título deste estudo, pretendemos pois recuperar a mesma força dos contrastes que o dramaturgo espanhol tão bem pressentiu ao escrever o magistral Bodas de sangre. Por outro lado, este é um tipo de banquetes que contrasta fortemente com o que Plutarco cultiva nos Symposiaka, por exemplo. Por conseguinte, a utilização do tema do banquete acaba por ser também um instrumento para expressar as mundividências antigas do caos e do cosmos, da desordem e da ordem.

Ao considerarmos o trabalho de Plutarco como biógrafo-historiador, o recurso a esta metodologia leva-nos necessariamente a colocar outras questões. Se estamos perante a utilização de motivos literários e de topoi com funções estéticas, que lugar há para a factualidade dos acontecimentos narrados pelo autor? Quando pesquisou informação e a recolheu em autores precedentes, tê-la-á Plutarco reproduzido acriticamente? E se o fez, terá sido de forma intencional ou não intencional? Por outras palavras, terá Plutarco descrito e registado acontecimentos tal como lhe foram dados a conhecer ou recriou-os e enriqueceu-os, recorrendo a instrumentos suficientemente conhecidos na sua época e providenciados por tradições literárias anteriores? Por conseguinte, é Plutarco um historiador ou um erudito "contador de histórias"? ${ }^{60}$ Estas são

\footnotetext{
${ }^{57} \mathrm{~J} .$, AJ 9, 233-235; 2Rs 15,25. Outros exemplos joséficos podem ser lidos em G. PAuL, 1991.

${ }^{58}$ Ver nosso estudo, 2001.

${ }^{59}$ Idem. Efectivamente, já o Nícias de Plutarco confessava que os banquetes eram ocasiões propícias a conflitos, Plu., Nic. 5, 1.

${ }^{60}$ Sobre o ambiente cultural e historiográfico do tempo de Plutarco, ver J. SirinelLi, 2000; F. Frazier, 1996; P. A. Stadter, 1992; A. Momigliano, 1971. Como referiu A. Lesky, 1995, p. 862, a Plutarco nunca "preocuparam as conexões históricas ou a etiologia política no sentido de Tucídides: só lhe interessam as grandes figuras humanas, cujos traços característicos... se manifestam não apenas nas grandes acções, mas também em gestos muito pequenos, e em muitos ditos".
} 
questões que naturalmente se colocam na sequência das nossas reflexões, mas cujas respostas exigem outro tempo e outro lugar de escrita ${ }^{61}$.

\section{Bibliografia CITADA}

Boling, R. G., The Anchor Bible - Judges, New York, 1975.

Bowie, A. M., "Fate may harm me, I have dined today: Near-Eastern Royal Banquets in Herodotus", Pallas, 61 (2003) 99-109.

Brenk, F. E., "Antony-Osiris, Cleópatra-Isis. The end of Plutarch's Antony", in P. A. Stadter (ed.), Plutarch and the historical tradition, London/New York, 1992, pp. 159-81.

Coulet, C., "Boire et manger dans l'Enquête d'Hérodote”, BAGB, 41 (1994) 56-70.

Dottin-Orsini, M., “O banquete de Herodes”, in M. Dottin-Orsini (ed.), Salomé, Lisboa, 1998, pp. 13-68.

Edmunds, L., "Theognis 815-18 and the Banquet of Attaginus", CPh, 82/4 (1987) 323-25.

Ferreira, L. N., Sacrifícios de crianças em Eurípides, Coimbra, 1996.

Mobilidade poética na Grécia Antiga. Uma leitura da obra de Simónides, Coimbra, 2005.

Flory, S., The Archaic Smile of Herodotus, Detroit, 1987.

Frazier, F., Histoire et Morale dans les Vies parallèles de Plutarque, Paris, 1996.

Gunkel, H., The Legends of Genesis. The Biblical Saga \& History, New York, 1964 (1a ed., 1901).

Halm-Tisserant, M., Cannibalisme et immortalité. L'enfant dans le chaudron en Grèce ancienne, Paris, $2007^{2}$.

Jung, C. G. \& Kerényi, C., Science of Mythology. Essays on the Myth of the Divine Child and the Mysteries of Eleusis, London/New York, 2002.

Knapp, B. L., "Herodias/Salome: Mother/Daughter Identification", in IDEM, Women in Myth, New York, 1977, pp. 87-110.

Lesky, A., História da Literatura Grega, Lisboa, 1995.

Momigliano, A., The Development of Greek Biography, Cambridge/MA, 1993.

${ }^{61}$ Esta problemática foi também abordada por F. E. BRENK, 1992, e por nós próprios, 2002, quando analisámos a presença do mitema de Ísis e Osíris na composição das biografias de António e Cleópatra. Cumpre-nos agradecer ao Prof. Doutor José Augusto Ramos, com quem discutimos várias das ideias que aqui apresentamos. 
Nunes Carreira, J., História antes de Heródoto, Lisboa, 1993.

Paul, G., "Symposia and Deipna in Plutarch's Lives and in other Historical Writings", in W. J. Slater (ed.), Dining in a Classical Context, Ann Arbor, 1991, pp.157-69.

Ramos, J. A., "Judite. A heroína fictícia e a identidade nacional de Israel", in D. F. LeÃo et al. (eds.), Mito clássico no Imaginário Ocidental, Coimbra, 2005, pp. 43-58.

Rodrigues, N. S., "História, Filologia e Problemáticas da Antiguidade Clássica", in M. F. ReIs (ed.), Rumos e Escrita da História. Estudos em Homenagem a A. A. Marques de Almeida, Lisboa, 2007, pp. 643-59.

"Messalina ou Aphrodita Tragica in Vrbe", in A. Ventura (ed.), Presença de Victor Jabouille, Lisboa, 2003, pp. 513-34.

"O Vinho, elemento do cosmos e do caos na cultura grega", in J. Maldonado Rosso (ed.), Actas do I Simposio de la Asociación Internacional da Historia e Civilización de la Vid y el Vino I, Cádiz, 2001, pp. 243-56.

"Plutarco, historiador dos Lágidas: o caso de Cleópatra VII Filopator", in Actas do Congresso Plutarco Educador da Europa, Porto, 2002, pp. 12749.

Sirinelli, J., Plutarque. Un philosophe dans le siècle, Paris, 2000.

SoAres, C., "Decadência na corte persa: um soberano inconstante e uma rainha-mãe vingativa na Vida de Artaxerxes", in C. SoAres et Al. (eds.), Ética e Paideia em Plutarco, Coimbra, 2008, pp. 51-68.

A morte em Heródoto. Valores universais e particularismos étnicos, Lisboa, 2003.

Stadter, P. A. (ed.), Plutarch and the historical tradition, London, New York, 1992.

Strid, O., "Voiceless victims, memorable deaths in Herodotus", CQ, 56/2 (2006) 393-403.

Titchener, F. B., "Everything to do with Dionysus: Banquets in Plutarch's Lives", in J. G. Montes Cala et al. (eds.), Plutarco, Dioniso y el vino. Actas del VI Simposio Español sobre Plutarco (Cádiz, 14-16 de Mayo, 1998), Madrid, 1999, pp. 491-500.

Wolff, E., “Das Weib von Masistes”, Hermes, 92 (1964) 51-8. 